\title{
Pre-purchase and post-purchase behaviour of farmer for fertilizers in Nagar and Shrirampur tahsil
}

\section{S.B. Magar and A.S. Kshirsagar}

Received : 24.10.2018; Revised : 06.03.2019; Accepted : 20.03.2019

\begin{abstract}
This study was conducted in between July 2018 and Sept. 2018 on a sample of 200 farmers selected on convenience from 12 villages of two talukas of Ahmednagar district of Maharashtra. Primary data were collected by sampling method on pretested semi-structured schedules. The finding suggested that about 30 per cent and 40 per cent farmers used water soluble fertilizers (WSFs) in Nagar and Shrirampur taluka, respectively. We selected Vedant fertilizer for sampling (Microsoft 6 and Amizone) to farmers because of these two products are newly launched and there are low sales in Nagar and Shrirampur taluka of Ahmednagar district. After sampling to 100 farmers of Nagar and 100 farmers of Shrirampur, we observed farmers purchase Vedant products. Water soluble fertilizers gives good result on crop after few days of sampling most of farmer observed healthy development of crop so farmers purchase nutrilex water soluble fertilizers.
\end{abstract}

KEY WORDS : Water soluble, Fertilizers, Sampling, Pre-purchase, Post-purchase, Consumer behaviour

How to cite this paper : Magar, S.B. and Kshirsagar, A.S. (2019). Pre-purchase and post-purchase behaviour of farmer for fertilizers in Nagar and Shrirampur tahsil. Internat. J. Com. \& Bus. Manage, 12(1) : 13-16, DOI: 10.15740/HAS/IJCBM/12.1/13-16. Copyright@ 2019: Hind Agri-Horticultural Society.

\section{MEMBERS OF THE RESEARCH FORUM}

Correspondence to:

S.B. Magar, College of Agriculture Business Management, Loni (M.S.) India

E-mail: swpanilmagar99@gmail.com

Authors' affiliations:

A.S. Kshirsagar, College of Agriculture Business Management, Loni (M.S.) India

E-mail: ashishpavara@gmail.com 